\title{
IMPLEMENTASI ENTREPRENEURSHIP DI LINGKUNGAN PENDIDIKAN: KASUS DI PONDOK PESANTREN ABU DARDA LOMBOK TENGAH NTB
}

\author{
Abdul Aziz Bagis ${ }^{1}$, Surati ${ }^{2}$, Mahyudin Nasir ${ }^{3}$, Iwan Kusumayadi ${ }^{4}$ \\ Manajemen Fakultas Ekonomi dan Bisnis Universitas Mataram \\ azis.bagis@unram.ac.id
}

\begin{abstract}
ABSTRAK
Tantangan bagi para pengelola lembaga pendidikan di daerah pedesaan di Indonesia masih sangat berat, terutama dari faktor pembiayaan maupun faktor sosial-budaya. Demikian halnya dengan tantangan yang dialami oleh lembaga pendidikan pondok pesantren Abu Darda di desa Sangkerang, dusun Balen Gagak, Praya timur, Lombok Tengah. Dengan keterbatasan sumber pembiayaan saat ini, Ponpes Abu Darda mampu menampung sebanyak 312 santri, dengan 34 ruang kelas untuk pendidikan taman kanak-kanak, Ibtidaiyah, Tsanawiyah dan Aliyah.

Peningkatan jumlah siswa dan guru, mengundang para penyumbang (pewakif) dari sejumlah masyarakat peduli pendidikan, untuk ikut berinvestasi lahan wakaf guna perluasan pondok pesantren Abu Darda. Kini muncul tantangan baru, yaitu bagaimana pemanfataan lahan wakaf tersebut secara produktif, sehingga mampu berkontribusi positif bagi kemajuan pondok pesantren Abu Darda. Sementara para pengelola Ponpes memiliki keterbatasan pengalaman maupun biaya produksi. Untuk itu dilaksanakan program dukungan yang nyata, dalam bentuk implementasi pelatihan dan pendampingan kewirausahaan Mandiri, dengan sasaran pemanfaatan lahan wakaf sesuai potensi dan luas lahan tersebut, dengan berbasis teknologi tepat guna. Hasil pelatihan intensif dan pendampingan berkelanjutan, mampu mendorong kemandirian pembiayaan operasional
\end{abstract}


pondok pesantren Abu Darda, untuk saat ini dan masa masa yang akan datang, sekaligus mengurangi ketergantungan dengan pihak donator.

Kata Kunci: Aktualisasi Potensi Insani, Kompetensi, Kewirausahaan Pondok, Produktivitas Lahan

\begin{abstract}
The challenges for managers of educational institutions in rural areas in Indonesia are still very heavy, especially from financing factors and socio-cultural factors. Likewise with the challenges experienced by the Abu Darda Islamic boarding school educational institution in Sangkerang village, Balen Gagak hamlet, East Praya, Central Lombok. With limited funding sources at this time, Ponpes Abu Darda is able to accommodate as many as 312 students, with 34 classrooms for kindergarten, Ibtidaiyah, Tsanawiyah and Aliyah education.

Increasing the number of students and teachers, invites donors (waqif) from a number of communities concerned about education, to participate in investing in waqf land for the expansion of the Abu Darda Islamic boarding school. Now a new challenge arises, namely how to use the waqf land productively, so that it can contribute positively to the progress of the Abu Darda Islamic boarding school. Meanwhile, Ponpes managers have limited experience and production costs. For this reason, a real support program is implemented, in the form of implementing training and mentoring for Mandiri entrepreneurship, with the target of using waqf land according to the potential and area of the land, based on appropriate technology. The results of intensive training and ongoing assistance, are able to encourage independence in the operational financing of the Abu Darda Islamic boarding school, for now and in the future, while reducing dependence on donors.
\end{abstract}




\section{Jurnal ABDIMAS INDEPENDEN}

Vol. 2, No. 1, Mei 2021

Keywords: Actualization of Human Potential, Competence, Pondok Entrepreneurship, Land Productivity

\section{PENDAHULUAN}

Kehadiran pondok pesantren khususnya pondok pesantren Abu Darda' sebagai sarana tarbiyatul ummat merupakan solusi, yang kami harapkan mampu menghantarkan masyarakat kepada suatu sikap yang dilandasi oleh nilai-nilai Ke Ilahian. Kita tidak bisa menapikan dan menutup mata betapa besar pengaruh dunia globalisasi terhadap perubahanperubahan yang terjadi disekitar kita terutama generasi muda, sehingga kehadiran pesantren sebagai lembaga pendidikan Islam akan semakin menjadi alternatif solutif yang efektif. Kedepan Pesantren sebagai lembaga pendidikan Islam diharapkan mampu memiliki nilai jual tinggi daya kompetitif yang tidak kalah dengan lembaga- lembaga pendidikan lain, demikian halnya dengan pondok pesantren Abu Darda' yang merupakan lembaga pendidikan Islam yang terletak di desa Sengkerang, Kecamatan Praya Timur Lombok Tengah dengan posisi geografisnya yang cukup strategis berada ditengah komunitas dan lingkungan masyarakat yang memiliki antusias yang tinggi terhadap keberadaan lembaga pendidikan agama yang memadai untuk menjadi lembaga alternatif utama bagi masyarakat (stackholder) maupun santri pengguna jasa agar proses pembelajaran maupun hasil yang diharapkan dapat tercapai sesuai yang diharapkan. Dengan tujuan membantu pemerintah untuk ikut mencerdaskan anak bangsa, terutama yang tinggal di pelosok dari keluarga tidak mampu, maka pada tahun ajaran 2014/2015 dibuka pendidikan Madrasah Tsanawiyah. tahun 2016/2017 dibuka TK Islam dan pada tahun ajaran 2017/2018 dibuka Madrasah Aliyah. Terakhir pada tahun ajaran 2018/2019 dibuka Madrasah Ibtidaiyah. santri yang belajar di Abu Darda, awalnya hanyalah dari masyarakat sekitar. Kini murid Abu Darda, 
berdatangan dari kabupaten Lombok Timur, Lombok Barat, Sumbawa Barat, Bima, Dompu dan Nusa Tenggara Timur.Dalam rangkamenggapai visi terwujudnya generasi yang shalih secara spiritual, intelektual dan sosial, maka upaya selanjutnya dijabarkan ke dalam misi pondok pesantren Abu Darda', menanamkan aqidah Islamiyah yang berdasarkan kepada Al-Qur'an dan As-Sunnah sesuai dengan pemahaman para sahabat dan orang-orang shalih terdahulu, mempraktikkan ibadah yang benar yang berlandaskan kepada dalil yang diterima, membiasakan akhlak yang mulia dalam kehidupan sehari-hari, melakukan proses tarbiyah (pendidikan) dan tashfiyah (pemurnian) dalam semua aspek ajaran agama dan melakukan bimbingan dan pendampingan berkesinambungan kepada anak didik dan masyarakat.

Tantangan penambahan jumlah para santri/i pondok pesantren Abu Darda yang terus mengalami kenaikan tersebut, sekaligus membuktikan peminat masyarakat pedesaan Sangkerang dan sekitarnya untuk memperoleh pendidikan pesantren, relatif cukup tinggi. Keterbatasan kemampuan sosial ekonomi para santri kurang mendukung kebutuhan kebuhan biaya operasional Pondok pesantren Abu Darda'. Sementara jumlah prasarana pondok pesantren Abu Darda' meliputi sarana dan prasarana belajar, yang sepenuhnya atas dukungan lahan wakaf $(2,5$ hektare) bersumber dari masyarakat peduli pendidikan dari NTB maupun luar negeri (Saudi Arabia).Tantangan pisik lain yang dihadapi pondok pesantren Abu Darda' meliputi: akses jalan menuju pondok pesantren Abu Darda' belum beraspal, kurangnya bimbingan dan pendanpingan dari dari pemerintah maupun swasta, minimnya kemampuan orang tua santri/i dalam dukungan materi dan lainnya, kondisi masyarakat dan santri/l pada umumnya terdiri dari petani miskin dengan tingkatan ekonomi pertengahan ke bawah dan masih kurangnya sarana belajar siswa baik berupa buku, media dan lainnya. Bertitik tolak dari tantangan yang sedang dihadapi oleh para pengelola pondok pesantren Abu Darda' saat ini, maka 


\section{Jurnal ABDIMAS INDEPENDEN}

Vol. 2, No. 1, Mei 2021

dipandang tepat, penyelenggaraan pelatihan dan pendampingan kewirausahaan mandiri, guna memaksimalkan berbagai potensi para pengelola dan ketersediaan lahan wakaf secara produktif. Implementasi entrepreneurship pendidikan di lingkungan pondok Abu Darda, sekaligus melanjutkan berbagai kegiatan dan dukungan manajerial yang pernah dilakukan oleh berbagai pihak, baik dari pemerintah daerah Lombok Tengah maupun para peduli pendidikan dan ahli manajemen pendidikan dari Saudi Arabia. Implementasi entrepreneurship di lingkungan pondok pesantren Abu Darda, diharapkan mampu melengkapi kemajuan manajemen pendidikan internal, yang menghasilkan berbagai penguatan informasi teknologi pondok dan terus berlangsung selama ini. Perlunya pemanfaatan lahan dan prasarana pendidikan menjadi makin produktifdengan cara bertumpu pada pengembangan semangat dan kemampuan kewirausahaan para pengelola pondok pesantren Abu Darda, sekaligus menjadi model bagi pesantren di Nusa Tenggara Barat.

\section{METODE KEGIATAN}

Dengan melakukan pemetaan potensi dan tantangan yang dihadapi oleh pondok pesantren Abu Darda, maka metoda implementasi entrepreneurship yang dipilih adalah pelatihan langsung dan pendampingan kepada para pengelola pondok, meliputi para ustad dan guru serta staf karyawan yang ikut menentukan kemajuan pondok pesantren selama ini. Metoda pelaksanaan yang dipilih sesuai tantangan yang dihadapi Pondok pesantren Abu Darda adalah pelatihan dan pendampingan kewirausahaan. Program pelatihan yang dimulai dengan memunculkan sikap positif dengan cara pemahaman asumsi dan keyakinan dasar akan potensi yang tertanam (embedded) pada para pengelola pondok pesantren. Selanjutnya pembentukan sikap dan prilaku produktif yang kreatif dan inovatif serta keberanian mengambil resiko secara 
terukur. Untuk mendukung penguatan kontribusi sikap terhadap prilaku pproduktif pengelola maka dipaparkan hasil pemetaan iklim institusional pondok pesantren Abu Darda pada saat ini. Metoda pelaksanaan pelatihan dan pendampingan kewirausahaan para pengelola Pondok pesantren Abu Darda, meliputi, tahap pengenalan dan pembentukan pola pikir produktif dengan melakukan stimulan sikap bagi para pengelola pondok pesantren Abu Darda' dalam rangka memanfaatkan potensi insani para pengelola Pondok pesantren Abu Darda, diikuti dialog pemetaan iklim lingkungan internal yang dialami para pengelola pondok sesuai tantangan yang dihadapi pesantren Abu Darda saat ini. Peningkatan kompetensi kewirausahan meliputi keterampilan mental, manual, sosial dan keterampilan verbal yang dilengkapi pengetahuan substansial dan kontekstual. Menyelesaikan masalah yang dihadapi pondok pesantren Abu Darda, diawali sesuai dengan tahapan metoda di atas, sekaligus mengimplementasikan 7 program berikut, yang meliputi: membangun pola pikir produktif dengan melakukan stimulan sikap para pengelola pondok pesantren Abu Darda' sesuai tantangan saat ini. Mendiskusikan hasil pemetaan iklim lingkungan internal yang dialami para pengelola pondok pesantren Abu Darda. Pengenalan potensi insani para pengelola pondok pesantren Abu Darda. Pelatihan peningkatan kompetensi kewirausahan meliputi keterampilan mental, manual, sosial dan keterampilan verbal yang dilengkapi pengetahuan substansial dan kontekstual. Pengembangan kemampuan Kewirausahaan pertanian dan peternakan dan pengembangan kemitraan (net-working) secara sinergis dengan mempersiapkan kolaborasi berbagai pihak yang mampu memberikan dukungan eksternal sehingga tercapai peningkatan kinerja para pengelola pondok pesantren Abu Darda. 


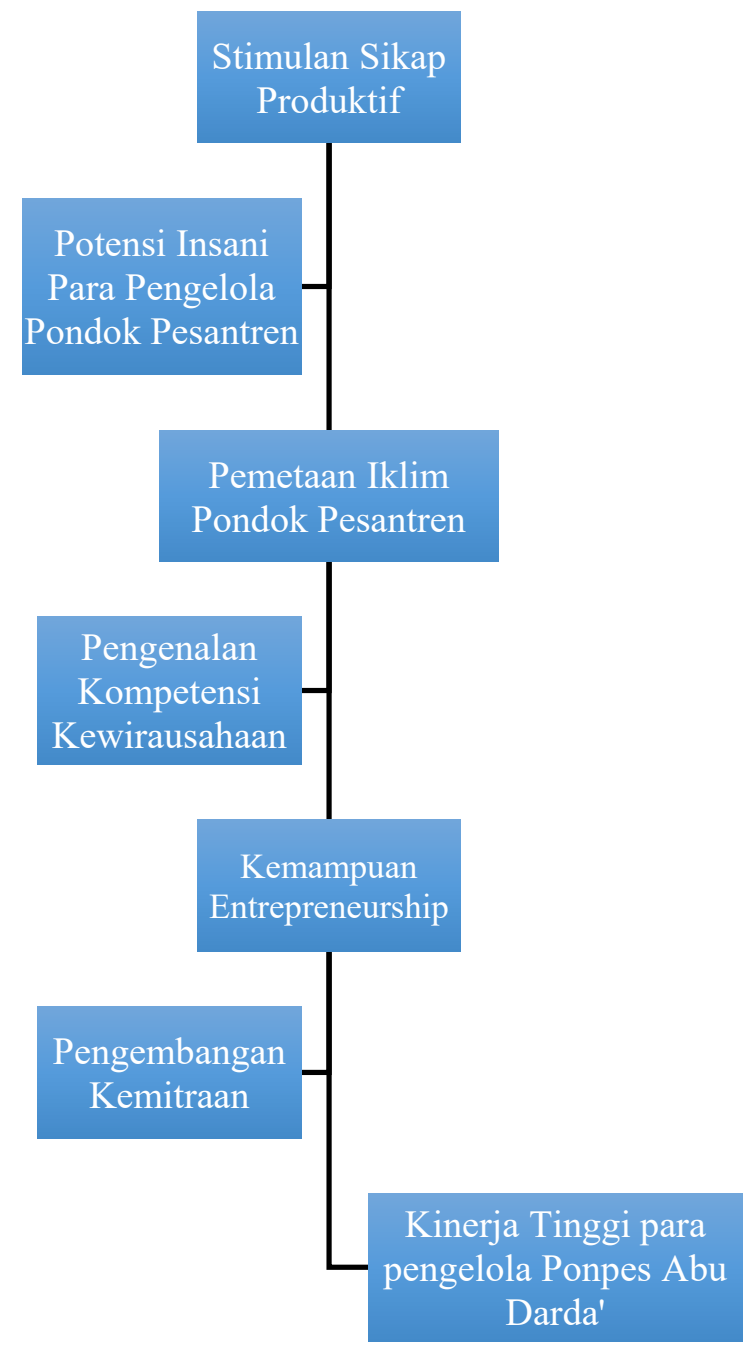

Gambar 1. Tahapan Metoda Pelatihan dan Pendampingan Entrepreneurship

Untuk meningkatkan efektivitas pelatihan entrepreneurship di bidang pendidikan pondok pesantren, dipilih metoda yang mampu mencerahkan potensi insani para pengelola pondok, sekaligus memanfaatkan segenap kompetensi dan sumber daya pondok Abu Darda secara optimal. Pendekatan pelatihan entrepreneurship dilakukan secara terpadu antara aktualisasi potensi insani dengan kompetensi para pengelola pondok pesantren Abu Darda, dengan demikian dihasilkan model pengembangan entrepreneur pendidikan sebagaimana tampak pada gambar-gambar berikut. 
Kekuatan Karakter (Kebajikan \& Potensi) dari Pekerja sebagai Manusia Bersumber Daya

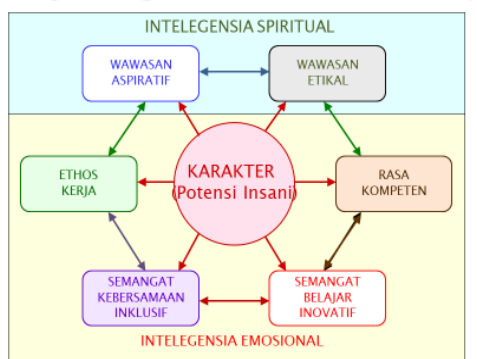

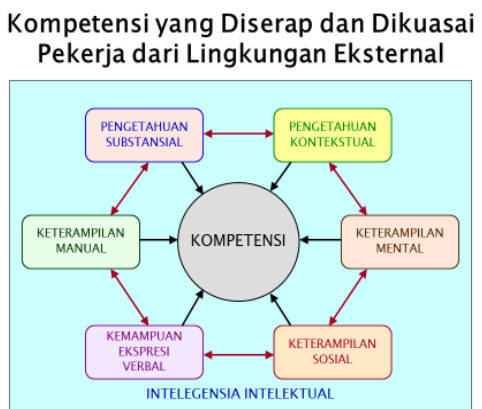

Gambar 2. Pembangunan karakter atau potensi insani dan kompetensi

\section{Pengembangan Entrepreneur Pendidikan}

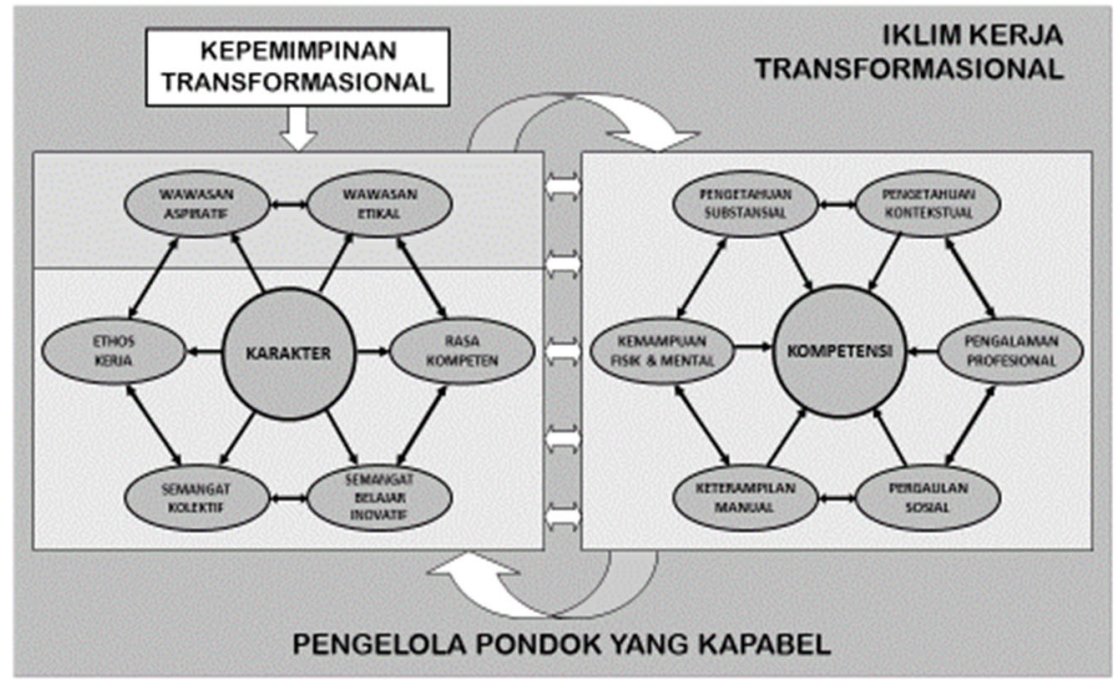

Gambar 3. Model Pengembangan Entrepreneur Pendidikan Pesantren

\section{HASIL DAN PEMBAHASAN}

Program pelatihan dan pendampingan entrepreneurship pendidikan di lingkungan pondok pesantren Abu Darda, pada dasarnya menghasilkan berbagai kiat untuk dapat membangun kekuatan cita-cita dan semangat para pengelola, sekaligus diyakini sebagai sumber utama untuk memanfaatkan potensi lahan dan sarana pendidikan yang sudah ada, menjadi makin produktif dan bermanfaat.Pengabdian kepada Masyarakat dilaksanakan dalam skemaProgram pelatihan dan pendampingan para pengelola pondok pesantren Abu Darda Lombok Tengah Proses 


\section{Jurnal ABDIMAS INDEPENDEN}

Vol. 2, No. 1, Mei 2021

pengabdian kepada masayrakat akan dilaksanakan dari dalam perioda tahun 2019 di pondok pesantren Abu Darda Praya Timur Kabupaten Lombok Tengah. Anggota terdiri dari 4 orang dosen yang berasal dari Universitas Mataram yang terdiri dari satu orang ketua dan 3 orang anggota. Hasil akhir dari pelatihan dan pendampingan, pada dasarnya membangun potensi insani para pengelola pondok, dalam wujud semangat pembaharuan (inovatif learning spririt), semangat percaya diri (self efficacy), semangat kerj keras (ethos), semanangat kerjasama terbuka (inclusive) yang diawali dengan pemaknaan cita-cita yang prgresif (aspratif) dan bernilai luhur (ethic) sebagai arah kemajuan bersama.Setelah memunculan potensi insani para pengelola pondok pesantren, terutama para ustad dan staf Abu Darda, maka dikenalkan kiat-kiat mengembangkan entrepreneurship (competency) yang meliputi berbagai keterampilan, mulai dari keterampilan mental, keterampilan social, keterampilan verbal dan keterampilan manual. Selanjutnya hasil pemetaan lahan produktif diarahkan untuk mengembangkan bidang pertanian dan peternakan, khususnya budi daya kayu gaharu, yang pada saatnya dapat menjadi sumber bahan baku produksi minyak wangi yang bernilai ekonomi tinggi. Budi daya kayu gaharu direkomendasikan dengan cara menjalin kerjasama dengan dinas kehutanan kabupaten Lombok Tengah, sekalgus dapat mensuply kebutuhan pembibitan dan pendampingan teknis secara berkelanjutan. Sementara untuk persiapan produksi minyak kayu gaharu pada tahun ke-tiga sudah dapat dimulai dengan cara penyediaan alat penyulingan (distillation) sederhana sampai sarana teknologi tepat guna yang sudah tersedia di pasaran. Pemasaran minyak kayu gaharu relative tidak banyak kesulitan karena permintaan luar negeri, khususnya timur tengah sangat tinggi. Kemitraan yang sudah terjlin secara baik dengan para pihak di Saudi Arabia, diharapkan dapat menjadi jembatan atau jaringan bisnis (net-working), bagi pengembangan bisnis pondok esantren Abu 
Darda di masa yang akan datang. Hasil pelatihan dan pendampingan dapat ditindak lanjuti untuk waktu-waktu yang akan datang, dengan cara menjalin hubungan dan komunikasi team dengan pimpinan pondok pesantren Abu Darda, yang juga menjadi khatib jumat di sejumlah masjid di kota Mataram. Dengan kepemimpinan pondok yang berjiwa entrepreneurship, diharapkan kemajuan dan kesejahteraan para anggota pondok akan segera terwujud. Program pelatihan dan pendampingan para pengelola pondok pesantren Abu Darda Lombok Tengahtelah dimulai sejak tahun 2019 di pondok pesantren Abu Darda Praya Timur Kabupaten Lombok Tengah, dan insyaAllah akan dapat terus dilakukan secara formalmaupun informal. Kegiatan kunjungan dari paraanggota terdiri dari 4 orang dosen yang berasal dari Universitas Mataram yang terdiri dari satu orang ketua dan 3 orang anggota, dapat dilakuan sewaktu-waktu, terutama pada saat pendampingan diperlukan. Hasil pelatihan dan pendampingan kewirausahaan akan makin dirasakan di masa-masa yang akan datang, selama para pengelola pondok pesantren Abu Darda bersedia memunculkan segenap potensi insani mereka secara maksimal, sekaligus memadukannya dengan berbagai kompetensi yang dimiliki atau yang dimiliki oleh mitra pondok. Sejumlah karakteristik entrepreneurship yang meliputi kreatifitas, inovasi dan keberanian mengambil resiko secara terukur menjadi materi penting dalam pelatihan. Disepakati bahwa seorang ustad dan guru dapat menjadi seorang entrepreneur sejati, selama mereka siap dan mampu membangun karakter kreatif (creative), inovatif (inovatif) dan berani resiko (risk taking) secara terukur dan bukan spekulasi. Untuk membangun karakter tersebut, perlu diawali dengan kemunculan berbagai potensi insani, meliputi cita-cita yang kuat dan bernilai tinggi, dibarengi semangat pembaharuan, semangat percaya diri, semangat kerja keras, dan semangat kerjasama yang lebih terbuka, menjadi modal social (social net-working). Dengan kemunculan potensi insani para pengelola, maka dipastikan pemanfaatan segenap kompetensi 


\section{Jurnal ABDIMAS INDEPENDEN}

Vol. 2, No. 1, Mei 2021

para pengelola pondok dalam mengembangkan lahan produktif menjadi optimal dan berdaya guna tinggi.

Tabel 1: Sarana dan prasarana Ponpes Abu Darda

\begin{tabular}{|c|c|c|c|c|}
\hline No & Sarana / Prasarana & Jumlah & Sumber & Keterangan. \\
\hline 1 & Ruang Kelas & 34 Unit & Swadaya Masyarakat & Layak \\
\hline 2 & Masjid Pondok & 2 Unit & Swadaya Masyarakat & Layak \\
\hline 3 & Ruang Pimpinan Ponpes & 1 Unit & Swadaya Masyarakat & Layak \\
\hline 4 & Ruang TU & 1 Unit & Swadaya Masyarakat & Layak \\
\hline 5 & Ruang Perpustakaan & 1 Unit & Swadaya Masyarakat & Layak \\
\hline 6 & Asrama Santri/i & 10 Unit & Swadaya Masyarakat & Layak \\
\hline 7 & Ruang Laboratorium & 1 Unit & Swadaya Masyarakat & Layak \\
\hline 8 & Rak Buku/Al-Qur'an & 4 Set & Swadaya Masyarakat & Layak \\
\hline 9 & Koperasi Pondok & 2 Unit & Swadaya Masyarakat & Layak \\
\hline 10 & Papan Tulis & 11 Set & Swadaya Masyarakat & Layak \\
\hline 11 & Lapangan bermain & $900 \mathrm{~m} 2$ & Swadaya Masyarakat & Layak \\
\hline 12 & Bangku+Meja Siswa & 300 Set & Swadaya Masyarakat & Layak \\
\hline 13 & Bangku+Meja Guru & 30 Set & Swadaya Masyarakat & Layak \\
\hline 14 & Komputer + Printer & 4 Set & Swadaya Masyarakat & Layak \\
\hline 15 & Buku Bacaan Santri & 500 Jenis & Swadaya Masyarakat & Layak \\
\hline 16 & Kitab Pegangan Ustaz & 14 Jenis & Swadaya Masyarakat & Layak \\
\hline 17 & Tempat Wudhu & $6 \mathrm{bh}$ & Swadaya Masyarakat & Layak \\
\hline 18 & Kamar Mandi Santri/i & $10 \mathrm{bh}$ & Swadaya Masyarakat & Layak \\
\hline 19. & Kamar Kecil Santri/i & 15 Unit & Swadaya Masyarakat & Layak \\
\hline 20. & Lahan kebun dan sawah & $2.500 \mathrm{~m} 2$ & Wakaf dari Donatur & Potensial \\
\hline
\end{tabular}




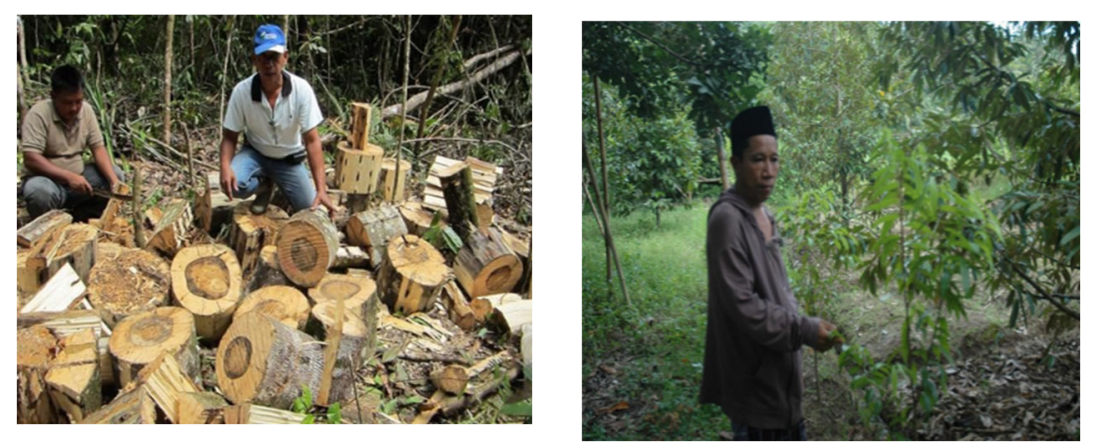

Gambar3. Model budi dayatanaman kayu gaharu

\section{SIMPULAN DAN SARAN}

\section{Simpulan}

1. Implementasi program pelatihan dan pendampingan kewirausahaan (entrepreneurship) pendidikan pada para pengelola pondok pesantren Abu Darda, dijalankan secara informal, dengan melakukan dialog intensif bagi para peserta.

2. Implementasi modal entrepreneurship yang dilandasi nilai-nilai kebajikan, InsyaAllah pondok pesantren Abu Darda akan berkembang menjadi pondok pesantren modern yang mampu mensejahterakan para pengelola sekaligus santri-santrinya.

3. Implementasi hasil pelatihan entrepreneurship akan selalu menjadi pendorong strategis bagi kemajuan pondok pesantren, di tengah berbagai tantangan yang makin bergejolak (turbulent) dewasa ini.

4. Penguatan nilai-nilai kebajikan (values) yang selama ini diajarkan di lingkungan pondok pesantren sekaligus diharapkan mampu menguatkan proses pembangunan karakter secara berkelanjutan.

5. Pemanfaatan ketersediaan lahan produktif dan sarana pembelajaran yang telah diwaqafkan dapat segera dioptimalkan.

\section{Saran}

1. Program pendampingan dapat juga dilanjutkan oleh para pihak internal pondok pesantren Abu darda, terhadap para santri-santri mereka. 


\section{Jurnal ABDIMAS INDEPENDEN}

Vol. 2, No. 1, Mei 2021

2. Pelajaran kewirausahaan mulai dikenalkan sejak santri dasar, sekaligus dilibatkan pada berbagai kegiatan produktif yang dimulai dikembangkan di lingkungan pondok pesantren Abu Darda.

3. Diupayakan untuk melaksanakan Kerjasama dengan pihak terkait seperti dinas pendidikan, dinas koperasi dan UMKM serta dinas pertanian dan peternakan Kabupaten Lombok Tengah

\section{UCAPAN TERIMA KASIH}

Pelaksanaan kegiatan Pengabdian Kepada Masyarakat ini telah melibatkan berbagai pihak, oleh karena itu pada kesempatan ini kami mengucapkan terima kasih dan penghargaan kepada :

1 LPPM UNRAM selaku koordinator pelaksanaan pengabdian kepada masyarakat.

2 Fakultas Ekonomi dan Bisnis Universitas Mataram dan BP2EB Fakultas Ekonomi dan Bisnis Universitas Mataram.

3 Lembaga pendidikan pondok pesantren Abu Darda di desa Sangkerang, dusun Balen Gagak Praya timur Lombok Tengah.

\section{DAFTAR PUSTAKA}

Bae, Tae Jun, Qian, Shanshan, Miao, Chao and Fiet, James O. (2014), The Relationship between Entrepreneurship Education and Entrepreneurial Intentions: a Meta-Analytic Review, Entrepreneurship: Theory and Practice, Vol. 38, No.2; pp.217

Bagis AA (2013), Kajian Entrepreneurship berbasis Keunggulan Kreatif, disampaikan pada seminar Nasional APMMI II Universitas Mataram.

Bagis AA (2015), Role of Virtual Capital in Business Development for the Ummah, International Conference and Ph.D. Colloquium on Islamic Economics and Finance 2015 
Bagis AA (2015), Pengembangan Entrepreneurship berbasis Potensi Insani Bisnis: Kasus para mahasiswa PTN di Nusa Tenggara Barat, penelitian Strategis Nasional, Kementrian Riset, teknologi dan Pendidikan Tinggi Republik Indonesia.

Bagis AA (2016), Pengembangan Entrepreneurship berbasis Potensi Insani Bisnis: Kasus para mahasiswa PTN di Sulawesi Selatan, penelitian Strategis Nasional, Kementrian Riset, teknologi dan Pendidikan Tinggi Republik Indonesia.

Bagis AA (2018), Implementasi Model Pengembangan Entrepreneurship para mahasiswa, penelitian Pascasarjana Universitas Mataram.

Enombo,J.P,.Hassan,S.L,.Iwu,C.G.,(2015),Nationalising the Introduction of Entrepreneurship Education in Gabon, Environmental Economics, Vol.6,Issue4

Ernest,K., Matthew,S.K. \& Samuel A.K.,(2015), Towards Entrepreneurial Learning Competencies : The Perspective of Built Environment Students, Higher Education Studies: Vol.5, No.1;2015

Tsoukatos, Evangelos (2014), Perceptions of entrepreneurial personality traits: Evidence from Greece, World Review of Entrepreneurship, Management and Sustainable Development, Vol. 10, No. 2; pp.179 